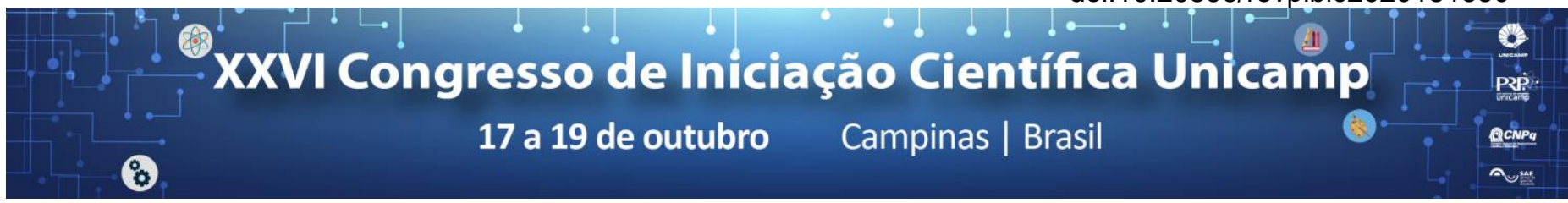

\title{
Um estudo sobre o projeto arquitetônico e sua construção do Espaço Natura de Roberto Loeb
}

\section{Vinícius Beraldo Vieira*, Ana Maria Tagliari Florio - orientadora}

\section{Resumo}

Esta pesquisa tem como objeto de investigação o Espaço Natura, do arquiteto Roberto Loeb, projeto desenvolvido entre 1996 e 2001, situado na cidade de Cajamar, SP. O objetivo desta pesquisa é o estudo e compreensão do projeto de arquitetura e sua construção, com enfoque nas soluções conceituais, técnicas e construtivas adotadas pelo arquiteto, envolvendo assim conhecimentos sobre projeto de arquitetura, engenharia, suas etapas, metas e obra construída.

\section{Palavras-chave:}

Roberto Loeb, análise de projeto, arquitetura industrial.

\section{Introdução}

Roberto Loeb, arquiteto graduado na Universidade Mackenzie, trabalhou para Rino Levi e Telésforo Cristofani antes de abrir seu próprio escritório na década de 1960 e se tornar um profissional reconhecido.

O objetivo desta pesquisa é a análise do projeto de arquitetura e sua construção, com enfoque nas soluções, desde conceituais, técnicas e construtivas, adotadas pelo arquiteto. O objeto de estudo em questão é o projeto do Espaço Natura, do arquiteto Roberto Loeb, desenvolvido entre 1996 e 2001, situado na cidade de Cajamar, SP.

\section{Resultados e Discussão}

Um dos principais projetos de arquitetura realizado nas últimas décadas no Brasil, segundo Fernando Serapião (Revista Monolito n.25, 2015, p.22), o Espaço Natura (1996-2001) destaca-se por ser referência em inovação na arquitetura industrial quando comparado à indústria tradicional. Com arquitetura diferenciada, prima pela iluminação e ventilação natural, além de colocar o colaborador em papel central, quebrando o paradigma tradicional.

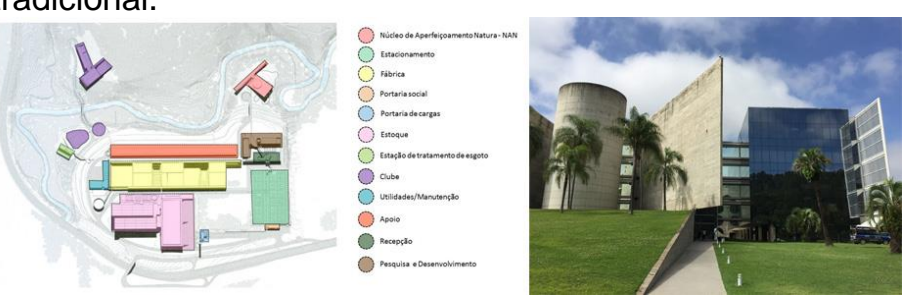

Figura 1. Implantação e foto do Espaço Natura. Fonte: Autor, 2017.

O complexo abriga indústria, escritórios e estoque. $\mathrm{O}$ projeto do Espaço Natura estabeleceu um novo paradigma para as indústrias, por sua inovação na organização do programa de necessidades, soluções sustentáveis, humanização dos ambientes, e construção de alta qualidade.

No que tange às soluções construtivas, destaca-se a tríade vidro, concreto e metal, principais materiais utilizados em sua construção. $O$ vidro tem papel fundamental no fechamento dos espaços, garantindo ainda sua integração com o ambiente, apresentado como transparente, cerigrafado ou refletivo, favorecendo ainda a iluminação natural e o conforto térmico. O concreto foi utilizado para criação da volumetria, compondo desde formas diferenciadas a estruturas em balanço, aliado às placas cimentícias. Por fim, o metal foi amplamente utilizado com finalidade estrutural, em pórticos e treliças, compondo passarelas e pontes.

Quanto às soluções de projeto, destaca-se o sistema de circulação como marca de interconexão dos espaços abertos e fechados do complexo, a partir das quais se traz a surpresa dos percursos nas sucessões dos espaços, trabalhando as sensações nos percursos.
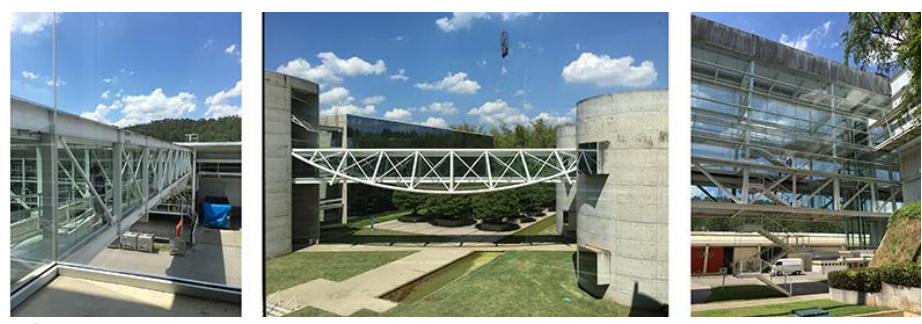

Figura 2. Passarelas. Fonte: Autor, 2017.

Ressaltam-se as soluções de sustentabilidade do projeto, desde sua concepção, que atribuiu funcionalidade aos espaços de maneira a favorecer a logística, acelerando o processo de reposição de matéria-prima e gerando economia dos processos, até a preocupação com o tratamento de água e esgoto do complexo, utilização de transporte interno movido a diesel e zelo com o bemestar dos colaboradores, além do aproveitamento dos sistemas de iluminação e ventilação naturais.

\section{Conclusões}

A experiência de Loeb como arquiteto contribuiu para as soluções inovadoras destacadas no projeto, incorporando características da Arquitetura Contemporânea no que tange ao contraste, tecnologia e sustentabilidade.

Por meio da realização desta pesquisa, pode-se destacar pontos importantes referentes a projeto e construção. $O$ Espaço Natura como um exemplar de arquitetura industrial diferenciada em relação ao modelo tradicional de espaço fabril; o conceito da empresa Natura sendo concretizado no Espaço Natura, envolvendo sustentabilidade, jovialidade, respeito ao usuário, respeito à natureza, transparência e solidez.

\section{Agradecimentos}

Agradeço a minha orientadora Prof $^{\underline{a}}$ Ana M. Tagliari Florio e ao PIBIC-SAE pelo incentivo e oportunidade de pesquisa.

\section{Referências}

CHING, Francis D. K. Architecture: Form, Space and Order. New Jersey, 2015, 4th edition;

Revista Monolito. LoebCapote. Edição 25, 2015;

ROSSO, Silvana Maria. Roberto Loeb: arquiteto. São Paulo: BEI Comunicação, 2011. 